\title{
The Young Augustine's Knowledge of Manichaeism: An Analysis of the Confessiones and Some Other Relevant Texts*
}

\author{
Johannes van Oort \\ Faculty of Theology \& Faculty of Religious Studies, University of Nijmegen I \\ Faculty of Theology, University of Pretoria \\ j.van.oort@planet.nl
}

\begin{abstract}
Mainly on the basis of an analysis of the relevant passages in the Confessiones, this article argues: 1 . that already the young Augustine, during his years as a Manichaean Hearer, acquired a thorough knowledge of Manichaeism; 2. that he obtained this thorough knowledge by his own reading and studying of Mani's and other Manichaean works. Moreover, it is argued that, in all likelihood, Augustine's Confessiones testify to the existence in the Latin West of Mani's so-called Image, the painted picture book illustrating his Gnostic doctrine.
\end{abstract}

\section{Keywords}

Augustine of Hippo, Confessiones, Mani, Manichaeism, Manichaean writings, Gnosticism, Roman Africa

Adelberto Davids: Septuagesimo Anno

\section{Introduction: The Status Quaestionis}

How closely was Augustine associated with Manichaeism? Curiously, opinions on this question still diverge. Sometimes the impression is created that, as far as their assessment of Augustine's early adherence to the main gnostic current of his times is concerned, scholars are driven (though, in all

\footnotetext{
*) This article was written mainly during November-December 2006 when, as a recipient of an International Science Liaison Grant from the National Research Foundation of the Republic of South Africa, I worked as a visiting researcher with Dr. Annemaré Kotzé at the Department of Ancient Studies of the University of Stellenbosch.
} 
probability, unconsciously) by a hidden agenda. Was the great Father of the Church, for some time, really a gnostic heretic, or was this Manichaean phase only very brief and passing, in actual fact 'no more than a spiritual side-tracking'?

Directly connected with this issue is the question of Augustine's knowledge of Manichaeism in general, i.e. the expert or non-expert manner in which the church father, in his various works, deals with Manichaean tenets. Should he be considered a person that bears witness to an intimate and even specialist knowledge of the 'religion of light', or should this knowledge be looked upon as only superficial or even erroneous? In addition, if it is concluded that Augustine did have access to any special knowledge, was this expertise gained already during his youth, or only in his later years? It would be interesting to investigate a wide range of major biographies and leading studies on the church father's theological and philosophical insights in order to see how, over the course of the past centuries until the present, scholarly opinions have been divergent and, more often than not, even contradictory. ${ }^{2}$

The same seems to go for the works of scholars who mainly deal with Augustine from another point of view, namely those who study Manichaeism. Isaac de Beausobre, for instance, the great scholar who may be

1) Thus, for instance, and most recently, Serge Lancel, Saint Augustine, London 2002, xvi. Cf. S. Lancel, Saint Augustin, Paris 1999, 10: 'une voie de garage spirituelle'. Similar attitudes one may observe in the work of other distinguished Augustine scholars. Here, I only refer to B. Studer who, in his Gratia Christi_Gratia Dei bei Augustinus von Hippo, Roma 1993, 167, states that Augustine was a Manichaean auditor for only nine months.

2) As far as I can see, the biography as well as the thoroughly in-depth study of Augustine's philosophy and theology that give full due to the Manichaean influence in his life (an influence the effects of which were pivotal in his thinking from his nineteenth year until the unfinished debate with Julian of Eclanum) still await to be written. Up to the present, most scholars have mainly discerned the Christian-Catholic and the Neo-Platonic elements in Augustine's thought. But apart from these primary currents there is, as a third element, the Gnostic current. In my opinion this current was a real and enduring factor in Augustine's life and world in the form of the Christian (!) ecclesia of the Manichaeans; it was through this church and its adherents that Augustine encountered Manichaean problems and patterns of thought which shaped his mind. To indicate it briefly: Manichaeism time and again shaped (and sometimes even determined) Augustine's exegesis of Biblical texts, his knowledge and refutation of 'apocryphal' writings, his assessment of the canon of Bible; it had its bearing on his Christology, soteriology, pneumatology, 'theology' proper and on his doctrines of sin, grace, and predestination; it exerted its influence upon his tenets of the two civitates, sex and (the transmission of) original sin. 
considered the founding father of Manichaean studies, ${ }^{3}$ did not always deem Augustine a trustworthy witness. ${ }^{4}$ For the next leading authority in the field, the famous Ferdinand Christian Baur, however, the church father frequently was his first and also a particularly reliable source for expounding Manichaean belief and practice. ${ }^{5}$

From more recent times we may mention the work of, amongst others, the eminent French Augustinian and Manichaean scholars Prosper Alfaric ${ }^{6}$ and François Decret. ${ }^{7}$ Generally speaking, although some differences exist, both specialists consider the church father in his extensive ouvre to be well informed and, more often than not, a very reliable witness. ${ }^{8}$ Besides,

3) Cf. J. van Oort, 'Würdigung Isaac de Beausobres (1659-1738)', in R.E. Emmerick et al. (Hgg.), Studia Manichaica. IV. Internationaler Kongreß zum Manichäismus, Berlin, 14.-18. Juli 1997 (Berichte und Abhandlungen der Berlin-Brandenburgischen Akademie der Wissenschaften, Sonderband 4), Berlin 2000, 658-666 and, in particular, G.G. Stroumsa, 'Isaac de Beausobre Revisited: The Birth of Manichaean Studies', ibidem, 601-612.

4) Isaac de Beausobre, Histoire (critique) de Manichée et du Manichéisme, I-II, Amsterdam 1734-1738 [latest reprint: Amsterdam 1988], e.g. I, 228 ('Je ne veux pourtant pas soûtenir, que S. Augustin ait déguisé le Systême Manichéen, afin d'en triompher' etc.) and II, 387389, 398. An important aspect for De Beausobre (cf. e.g. I, 227-231, 426, and 436-437; II, 739) was that Augustine was only an auditor, and thus, according to him, not directly acquainted with Mani's and other Manichaean writings.

5) F.C. Baur, Das manichäische Religionssystem nach den Quellen neu untersucht und entwikelt, Tübingen 1831 (repr. Göttingen 1928; Hildesheim-New York 1973), 7f., and then nearly passim.

6) P. Alfaric, L'Évolution intellectuelle de saint Augustin, I, Paris 1918, e.g. 215-225. On p. 218 Alfaric even remarks: 'De tous les auteurs connus qui ont écrit sur la religion de Mani, Augustin est sans doute celui qui nous fournit sur elle les renseignements les plus nombreux et, dans l'ensemble, les plus sûrs'.

7) F. Decret, Aspects du manichéisme dans l'Afrique romaine: Les controverses de Fortunatus, Faustus et Felix avec saint Augustin, Paris 1970, e.g. 31: 'Ces œuvres anti-manichéennes constituent un témoignage véritable sur le manichéisme qu'Augustin a bien connu, mais non sur tout le manichéisme'; idem, 'Le manichéisme présentait-il en Afrique et à Rome des particularismes régionaux distinctifs?', Augustinianum 34 (1994) 8 (repr. in Decret, Essais sur l'Église manichéenne en Afrique du Nord et à Rome au temps de saint Augustin: Recueil d'études, Roma 1995, 211): '...parfaitement informé, certes, de la situation du manichéisme dans les provinces romaines d'Afrique, dont il peut parler en expert', but with the correct caueat that 'l'évêque d'Hippone n'a pas voulu faire œuvre d'historien, mais que son témoignage doit toujours être reçu comme celui d'un polémiste'.

8) Apart from the fact (see previous note) that the polemist Augustine only knew Manichaeism as far as it was accessible to him in its Latin expressions, time and again Decret also refers to Augustine's (perhaps deliberate?) misunderstanding of a supposed Manichaean two souls theory, a dualistic concept of two 'gods', and of the Manichaeans' worship of the sun and the moon, among other things. 
during the past decades some other researchers have gone so far as to refer to Augustine's work in order to explain some peculiarities of Manichaean texts dating from much later centuries and completely different environments than fourth to fifth century Roman North Africa or Italy. Thus, in his commentary on references to Manichaeism in a Mazdaean apologetic work of the ninth century, Pierre Jean de Menasce deemed it sound scientific method to point out parallels with Augustine's work. ${ }^{9}$ Furthermore, in another groundbreaking study he wrote that there should be no doubt at all that Augustine's knowledge of Manichaean doctrine and practice was 'very precise and very complete' and that it could be 'checked' through comparison with texts from Central Asia and Egypt. ${ }^{10}$ Such a methodological appoach one also finds, for instance, in an article of J.P. Maher, when he stresses the fact that, in his work Contra Faustum, Augustine enumerates exactly the same five sons of the Manichaean Living Spirit, and in the same order, as they are listed in the Coptic Kephalaia. ${ }^{11}$ The same seems to go for some studies of the Belgian specialist Julien Ries. ${ }^{12}$ And, generally speaking, a typical result of much of the most important work of the German scholar Erich Feldmann may be considered to belong to the same category: while always proceeding very cautiously, he often arrives at the conclusion that Augustine's knowledge of Manichaeism is both unique and very trustworthy. ${ }^{13}$

9) P.J. de Menasce, Une apologétique mazdéenne du IXe siècle: Škand-Gumānīk Vičār. La solution décisive des doutes, Fribourg 1945, notably pp. 229 and 236. I owe this reference to J.K. Coyle's 2001 study referred to in note 19 (there 44 n. 5).

10) P.J. de Menasce, 'Augustin manichéen' in: Freundesgabe für Ernst Curtius zum 14. April 1956, Bern 1956, 83: 'nul ne songe à mettre en doute la connaissance très précise et très complète qu'Augustin avait prise de la doctrine et de la pratique manichéennes. Nous sommes en mesure de la contrôler à mesure que s'étend notre propre information grâce aux textes d'Asie centrale et d'Égypte'.

11) J.P. Maher, 'Saint Augustine and Manichaean Cosmogony', Augustinian Studies 10 (1979) 91-104. The reference is to $c$. Faust. XV, 6 and Keph. 91.

12) E.g. J. Ries, 'Jésus-Christ dans la religion de Mani. Quelques éléments d'une confrontation de saint Augustin avec un hymnaire christologique copte', Augustiniana 14 (1964) 437-454 and 'Une version liturgique copte de l'Epistola fundamenti de Mani réfutée par Saint Augustin?', Studia Patristica 11 (Texte und Untersuchungen 108), Berlin 1972, 341340. As regards his theories, however, see the critical remarks of G. Wurst, 'Bemapsalm Nr. 223. Eine liturgische Version der Epistula Fundamenti?', in A. Van Tongerloo \& S. Giversen (eds.), Manichaica Selecta. Studies presented to Professor Julien Ries..., Lovanii 1991, 391 399, and already Feldmann, Einflu $\beta$ (infra, n. 13), I, 240.

13) See e.g. many passages in his first and major-though, unfortunately, unpublishedwork: E. Feldmann, Der Einflu $\beta$ des Hortensius und des Manichäismus auf das Denken des 
While not denying particular nuances in various authors, the present state of research on Augustine's knowledge of Manichaeism may be outlined as follows. Although there are considerable differences between Manichaean texts stemming from such different regions as the Western part of the Roman Empire and Egypt on the one hand and Central Asia and China on the other, and from such distinctive eras as, for instance, the fourth or the tenth century CE, this book religion with its own fixed canon and settled hierarchy reveals a constant substratum of which, not least, Augustine's extensive œuvre provides us with a highly reliable account. It is in this way that, at different occasions in the course of a number of years, also the present writer has described both Manichaeism and Augustine's knowledge of it. ${ }^{14}$

\section{The Opinion of J. Kevin Coyle}

In the past years, however, J. Kevin Coyle has called into question this more or less explicit communis opinio of the majority of researchers. ${ }^{15}$ Though, in actual fact, Coyle does not doubt that, by and large, Augustine was well acquainted with Manichaeism, he emphatically points to a subject that is essential to him. According to Coyle, we should sharply

\footnotetext{
jungen Augustinus von 373, I-II, Diss. Münster 1975. Several of his later and often innovative studies are further elaborations of important sections of this work, particularly Feldmann's only book that appeared in print: Die "Epistula Fundamenti" der nordafrikanischen Manichäer, Altenberge 1987.

14) See e.g. J. van Oort, Jeruzalem en Babylon. Een onderzoek van Augustinus' De stad van God en de bronnen van zijn leer der twee steden (rijken), 's-Gravenhage 1986 (Zoetermeer $\left.1995^{4}\right)=$ Jerusalem and Babylon. A Study into Augustine's City of God and the Sources of His Doctrine of the Two Cities, Leiden-New York-Købnhavn-Köln 1991, for instance 45 and 224; idem, 'Augustin und der Manichäismus', Zeitschrift für Religions- und Geistesgeschichte 46 (1994) 126-142, esp. 128. See, for instance, also idem, 'Manichäismus', Die Religion in Geschichte und Gegenwart, Band V, Tübingen 2002, 732-741; 'Augustine and Manichaeism in Roman North Africa. Remarks on an African Debate and Its Universal Consequences', in: P.-Y. Fux e.a. (éd.), Saint Augustin: africanité et universalité. Actes du colloque international Alger-Annaba, 1-7 avril 2000, Tome I, Fribourg 2003, 199-210; idem, 'Augustine' and 'Manichaeism' in: W.J. Hanegraaf a.o. (eds.), Dictionary of Gnosis and Western Esotericism, Vol. I, Leiden-Boston 2005, 142-143.757-765.

15) A notable exception is L.J.R. Ort, Mani. A religio-historical description of his personality, Leiden 1967, 40-41, but his (all too brief) argument against Augustine's reliability is neither expert nor convincing.
} 
distinguish between knowledge which Augustine gained during his Manichaean period and knowledge he obtained during his later years. Coyle already briefly touched upon this question in his Fribourg dissertation, ${ }^{16}$ but he made it his main topic in two recent and, to a considerable degree, corresponding articles.

In the first article he states, amongst other things: 'As far as I know, van Oort is the only present-day scholar to have seriously taken up de Beausobre's question-how much did Augustine actually know about Manichaeism, and when did he know it?-, but without really distinguishing between knowledge gained in his Manichaean period and knowledge obtained after it. ${ }^{17}$ Focusing first on the sister treatises De moribus ecclesiae catholicae and De moribus Manichaeorum, van Oort then moved to the Confessions, Contra Fortunatum, and Contra Faustum, before concluding: "zwar nicht alles wei $\beta$ er, wohl aber sehr vieles" ${ }^{18}$ This is, I believe, essentially correct. But here, limiting the quest to what Augustine could have known as a Manichaean, we must curtail the range of texts examined to his early writings, especially the aforementioned two treatises De moribus. ${ }^{\prime 19}$

In a second study, the 2002 Villanova St. Augustine lecture published in the subsequent year, Coyle says inter alia: '... we must make a crucial distinction, between what Augustine could have known while a Manichaean, and what he found out later. ${ }^{20}$ Here again, and once more contrary to my views, Coyle opines that, during his Manichaean years, Augustine, as a Hearer, only heard readings of Mani's books and only heard about Manichaean ethics and doctrine: 'he quotes directly from a Manichaean text for the first time only in or about 393, explaining elsewhere that this writing

16) J.K. Coyle, Augustine's "De moribus ecclesiae catholicae": A Study of the Work, Its Composition and Its Sources, Fribourg 1978, 50-52.

17) The 'really' in Coyle's sentence will particularly refer to my remark in 'Augustin und der Manichäismus', 128: 'Damit wir unser Thema richtig ansteuern, möchte ich die beiden folgenden Punkte erörtern: I. Inwiefern lernte Augustin den Manichäismus kennen, in seiner manichäischen Zeit und später im Bischofsamt, und in welcher Form zeigte es sich ihm?'. See, for instance, also Jerusalem and Babylon, 42 and 45.

18) Cf. 'Augustin und der Manichäismus', 131.

19) J.K. Coyle, 'What Did Augustine Know about Manichaeism When He Wrote His Two Treatises «De moribus», in: J. van Oort, Otto Wermelinger and G. Wurst (eds.), Augustine and Manichaeism in the Latin West, Leiden-Boston-Köln 2001, 43-56 (quote p. 45-46).

20) J.K. Coyle, 'Saint Augustine's Manichaean Legacy', Augustinian Studies 34 (2003) $1-22(10)$. 
"came into my hands" when he was already a Catholic presbyter. ${ }^{21}$ In his refutation of Mani's Letter of the Foundation he clearly states that while he was a Hearer the writing in question was read to him. ${ }^{22}$ In addition, he frequently says that he heard, ${ }^{23}$ never that he actually read, any innermost Manichaean texts in those days: we need to take Augustine's Hearer status seriously. Over the course of his entire literary career he quotes from the Manichaean textual corpus only infrequently, in each instance from writings recently acquired. ${ }^{24}$

\section{Is Coyle's Position Tenable?}

I think it is worth the effort and, from a scientific point of view, even necessary to expound my view again and, when required, to explicitly show where and why, in my opinion, Coyle's position is untenable. I will do this here with a minimum of references to the published studies by both of us - the reader may know where to find and how to interpret them-, but with a maximum of attention to the relevant primary texts. Beforehand, however, and as a kind of early conclusion, I must acknowledge that, in essence, my standpoint is no other than the position already reached in 1986. But, here and now, and being twice explicitly challenged by this highly esteemed colleague, it is appropriate to review the whole issue once more and, as far as I am concerned, for the first time with this as the sole purpose of a separate study. Besides, and as a pleasant circumstance, it is

21) The reference is to retr. I, 22, 1 (CCL57, 63): 'Eodem tempore uenerunt in manus meas quaedam disputationes Adimanti, qui fuerat discipulus Manichaei.... (Here and in the subsequent notes my references to Augustine's works are in accordance with, e.g., the Augustinus-Lexikon).

22) With main reference to c. epist. Man. 5 (CSEL 25, 197): 'ipsa enim nobis illo tempore miseris quando lecta est, illuminati dicebamur a uobis'.

23) The reference is to mor. (= De moribus ecclesiae catholicae) I, 18, 34 (CSEL 90, 39): 'audite doctos ecclesiae catholicae uiros tanta pace animi et eo uoto quo uos audiui'; to mor. (= De moribus Manichaeorum) II, 8, 11 (CSEL 90, 96): 'unus e primatibus huius haeresis, quem familiarius et crebrius audiebamus'; and to mor. II, 12, 25 (CSEL 90, 110): 'cum studiose uos audiremus'.

24) With reference to Mani's Treasure of Life (nat. b. 44; c. Fel. II, 5 and I, 14); the Letter of the Foundation (c. ep. Man. 8, 11; nat. b. 42. 46; c. Fel. I, 1. 15); the Letter to Menoch (' but only after Julian of Eclanum had brought it to Augustine's attention': c. Iul. imp. III,166 and 172-173). 'He also acquired the work of Adimantus (retr. I, 22, 1) and writings of two of Mani's Western followers, Faustus and Secundinus'. The italics in the quoted passages are Coyle's. See Coyle, 'Augustine's Manichaean Legacy', 13-14. 
thanks to new discoveries that, in the meantime, the source material relevant to our topic has increased.

\section{The Testimony of Augustine's Confessiones}

At present no researcher may overlook the fact that, from the nineteenth to the twenty-eighth year of his life, Augustine was a Manichaean. Thus he clearly states himself at the beginning of Book IV of the Confessiones: 'During this same period of nine years, from the nineteenth year of my life to my twenty-eighth year, ${ }^{25}$ we were seduced and we were seducing. ${ }^{26}$ The expression 'this same period' refers to what has been related in the previous book. There, from conf. III, 6, 10 onwards, Augustine tells how he 'fell in' (incidi in) with the Manichaeans, and how those people (illi) used 'to sound off' (sonarent) about God 'frequently and in various ways' (frequenter et multipliciter), 'with mere voice' (uoce sola) 'and with the support of many huge tomes' (et libris multis et ingentibus). Their impressive books were used as the dishes (fercula) in which they, instead of the true God, 'served up the sun and the moon' (inferebantur... sol et luna). Augustine makes an explicit distinction between the things the Manichaeans said (dicebant) in their discourses, and those things they 'served up' (or 'brought in': inferebantur) by means of their books. Moreover, a little further on in the same passage, he returns to the role these books played in the mission activity of the Manichaeans: 'the dishes (once again: fercula) they placed before me (apponebantur adhuc mihi) contained splendid hallucinations'.

It may be evident that, already from the very beginning of his account of the Manichaeans and their missionary activity towards him, Augustine makes a marked distinction between their oral proclamation (uoce sola) on the one hand and the proclamation by means of their books on the other. ${ }^{27}$

25) That is, according to our common parlance, from the time he was 18 years old up to and including the time he was 27. Following P. Courcelle (Recherches sur les Confessions de saint Augustin, Paris 19682, 78), many scholars did suppose that Augustine's 19th year extended from 13 Nov. 373 to 13 Nov. 374. It was, however, from Nov. 372 to Nov. 373. Augustine clearly speaks of the 'annum aetatis meae', which we deliberately translate as 'the year of my life' (or: 'of my lifetime'). See already Jeruzalem en Babylon, 36 n. 150 (= Jerusalem and Babylon, 42-43, n. 150).

26) Conf. IV, 1, 1 (CCL 27, 40): 'Per idem tempus annorum nouem, ab undeuicensimo anno aetatis meae usque ad duodetricensimum, seducebamur et seducebamus....

27) Apart from 'et' in the passage quoted above ('uoce sola et libris') one may note the (often not translated!) adverb 'adhuc' in the next sentence ('et apponebantur adhuc mihi in illis 
The role they attached to their 'huge tomes' he does not explicitly detail. From the just quoted passages it is clear, however, that these books had a function which was supplementary to the oral discourses. Did, so one may ask, these tomes function as a specific illustration of their oral message? Indeed, and even in the most litteral sense, this seems to have been the case. For, apart from and in addition to what the 'loquacious' Manichaeans proclaimed orally, ${ }^{28}$ there was their missionary use of impressive books. These books functioned as the dishes in which they 'served up' (inferebantur) and 'placed before' (apponebantur) the young Augustine representations (phantasmata splendida: 'splendid hallucinations', 'clear fantasies', 'bright imaginations') of - in any case-the sun and the moon (sol et luna).

This information about supplementary books, placed before a person to be converted and containing 'bright imaginations' (phantasmata splend$i d a),{ }^{29}$ seems to be an indication of a hitherto unknown (and, to my knowledge, not even conjectured) aspect. According to my view we may catch here a unique glimpse of the likely detail that, also in fourth century Roman Africa, apart from the Manichaeans' oral message by means of discourses, there was a further illustration of their doctrine by means of pictorial books. If this is correct, which other books or book in particular (either existent in several huge copies, or subdivided in several parts: libris

ferculis phantasmata splendida'). Here, like elsewhere in Augustine's œuvre (e.g. conf. I, 6, 10: 'et transibunt adhuc alii [dies]'), 'adhuc' may be translated as 'besides', 'also', 'too' or 'even'.

28) Note also the significant in quorum ore and de ore eorum at the beginning of conf. III, 6,10 .

29) In all probability this refers in guarded terms to the drawings and graphics in the books. As may be inferred from the subsequent remarks in conf. III, 6, 10, the depictions of the sun and the moon were intended to be representations of God. In conf. III, 6, 11 Augustine speaks of the 'five elements, which take on different colours, each in accordance with one of the five caverns of darkness'. If our preceding analysis is correct, one may assume that the picture book(s) of the Manichaeans in Roman Africa also contained (coloured) delineations of these 'quinque elementa varie fucata propter quinque antra tenebrarum'.- The whole passage conf. III, 6, 10-11, like several other anti-Manichaean passages in Augustine's œuvre, seems to require a fresh analysis from the likely presence of picture books among the Manichaeans in the Latin West. In any case, a reference like 'Manichees had exquisitely decorated liturgical books, finely bound, as orthodox Churches outside great cities, had not' (Saint Augustine, Confessions. Translated with an Introduction and Notes by Henry Chadwick, Oxford 1991, 41 n. 16) is vague and, moreover, lacks specific evidence in regard to the supposed 'liturgical' (?) use. 
multis et ingentibus) would have been in use among the African Manichaeans than the famous (but, until now, not rediscovered) picture book of

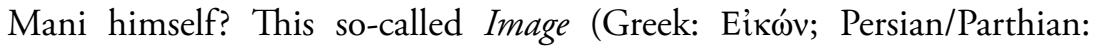
$\bar{A}$ rdahang) was a painted picture book illustrating the most essential aspects of Mani's doctrine. According to the majority of the researchers, this book probably was an appendix to, but different from Mani's most important canonical writing, i.e. the Living Gospel. ${ }^{30}$ Whether Mani's Fundamental Letter (Epistula Fundamenti), which was so well known in the Latin West, might be identified as the written commentary added to this Picture Book or Drawing still remains an open question. In any case, so it seems to me, in this account of his very first acquaintance with the Manichaeans, Augustine hints at their presentation of pictorial books. ${ }^{31}$

But, even if it is deemed not absolutely certain that they showed some sort of picture books, nobody will deny that Augustine, when recalling his very first acquaintance with the Manichaeans, explicitly speaks about their missionary use of books. It is these books that, explicitly as well, he mentions in the continuation of his life story. Though in the first account relevant to us he does not say that he himself read these books (in actual fact, he relates having seen them), an active reading of Manichaean books, and

\footnotetext{
30) Another and, in my view, even more likely possibility is that the Icon was designed to illustrate the contents of Mani's Pragmateia (or Treatise, Essay). See e.g. my introduction to J. van Oort \& G. Quispel, De Keulse Mani-Codex. Vertaald, ingeleid en toegelicht, Amsterdam 2005, 56-57. Perhaps it was this canonical writing of Mani's (and not his Living Gospel) that was also well known among the Western Manichaeans and, after the Epistula Fundamenti as the first and the Thesaurus as the second canonical text, belonged to the quinque auctores which, as 'scripturae Manichaei', were present during the second day of Augustine's disputation with Felix (see $c$. Fel. I, 14). See below on Augustine's anti-Manichaean 'pentateuch'.

31) This might be corroborated by his use of the verb imaginari a few lines further on in conf. III, 6, 10 (CCL 27, 32): 'At illa [sc. phantasmata quae apponebantur mihi in illis ferculis] nec similia erant ullo modo tibi, sicut nunc mihi locuta es, quia illa erant corporalia phantasmata, falsa corpora, quibus certiora sunt uera corpora ista, quae uidemus uisu carneo, siue caelestia siue terrestria: cum pecudibus et uolatilibus uidemus haec, et certiora sunt, quam cum imaginamur ea. Et rursus certius imaginamur ea quam ex eis suspicamur alia grandiora et infinita, quae omnino nulla sunt.' Besides, there might be a subtle reference to such a picture book when Augustine, speaking of the doctrine of the Manichaeans in conf. V, 10, 20 (CCL 27, 68), states: 'quam malignam mentem per illam terram repentem imaginantur'. One may also compare Augustine's reference to the Manichaeans in conf. IX, 4, 10 (CCL 27, 139): 'Volentes enim gaudere forinsecus facile uanescunt, et effunduntur in ea, quae uidentur et temporalia sunt, et imagines eorum famelica cogitatione lambiunt'.
} 
even a distinctive personal study of them, may be inferred from some subsequent passages.

When following the sequence of the account in the Confessiones, our next relevant passage is the story about an African and Catholic bishop to whom Monnica turned for help in the sorrows about her son. This person, otherwise unknown to us, ${ }^{32}$ is reported to have said to the troubled mother that her son 'by his reading will discover what that error (sc. the Manichaean haeresis) is and how vast an impiety. ${ }^{33}$ From the context, this 'reading' (legendo) almost certainly refers to Manichaean books: ${ }^{34}$ because, in the same passage, it is specifically said that this Catholic bishop, when he was a young boy, ${ }^{35}$ had been given to the Manichaeans by his mother and that 'he had not only read (legisse) nearly all their books (libri) but had even copied them'. Significantly, we also learn that, to this bishop, it had become clear 'without argument or proof of anyone' (nullo contra disputante et conuincente) that this sect (secta) ought to be avoided. ${ }^{36}$ By implication it is said here: Augustine, too, has to go this way; legendo he will discover the Manichaean error and impietas.

A next significant paragraph is Confessiones V, 3, 6. Though, with the previous analysis in mind, one might discover some pertinent but subtle indications in the text in-between the passage just discussed and this one, ${ }^{37}$

32) In several popular narrative accounts he is wrongly identified with Ambrose.

33) Conf. III, 12, 21 (CCL 27, 39): '... ipse legendo reperiet, quis ille sit error et quanta impietas'.

34) One might argue that it refers to the Christian holy scriptures in which the unknown bishop is just said to be 'well trained' ('episcopum ... exercitatum in libris tuis'). The sequel of the text, however, makes it far more likely that the reference is to the books of the Manichaeans, as it is perhaps also indicated by the beginning of the bishop's answer: 'sine illum $i b i$ ', that is: 'let him be there', namely in that Manichaean heresy. There he will make, 'legendo', his own (disillusive) discovery.

35) One may suppose: as a puer oblatus, like it is told of Mani himself in the Cologne Mani Codex (e.g. p. 11) and by the tenth century Arabic and Muslim writer al-Nadim in his Fihrist (see B. Dodge, The Fihrist of al-Nadim. A Tenth-Century Survey of Muslim Culture, New York-London 1970, vol. II, 774). Cf. e.g. J. van Oort, Mani, Manichaeism and Augustine. The Rediscovery of Manichaeism \& Its Influence on Western Christianity, Tblisi 1996 $\left(2001^{4}\right), 42$.

36) Conf. III, 12, 21 (CCL 27, 39): 'Simul etiam narrauit se quoque paruulum a seducta matre sua datum fuisse manichaeis et omnes paene non legisse tantum uerum etiam scriptitasse libros eorum sibique apparuisse nullo contra disputante et conuincente, quam esset illa secta fugienda: itaque fugisse'.

37) In conf. IV, 15, 24 (CCL 27, 52) Augustine speaks of 'lineamenta et colores et tumentes magnitudines' when discussing the contents of the first work he ever wrote, namely his 
it is here that one notices, for the first time, Augustine openly speaking of his reading of Manichaean books. At this point, he even specifies that he has read books of Mani. ${ }^{38}$ The relevant passage runs as follows: 'Nevertheless, many true statements (dicta) based on their observations of the Creation itself did I retain from these men (sc. 'the philosophers'). I noted ${ }^{39}$ their rationale $(\text { ratio })^{40}$ based on calculations, the order of seasons, and the visible manifestations of the stars. I compared this with the sayings of Mani (dicta Manichaei), which ${ }^{41}$ he has written on these subjects very copiously

(lost) De pulchro et apto. This is not only an evident indication of Manichaean terminology (like so many other things he notes about the contents of the work are Manichaean), but perhaps also a reminder of his acquaintance with a book like Mani's Drawing. In conf. IV, 16, 28 he makes mention of his reading and understanding of Aristotle's Categories 'alone', that is without the help of any interpreter, and in IV, 16, 30 he states that he had 'read by myself, and understood, all the books I could get hold of on the so-called liberal arts'. One would say: it is characteristic of the young Augustine to read (legere) and judge (intellegere) for himself. Why, then, would the Manichaean books (which were accessible to Hearers, see below) have been an exception to this habitual practice?

38) Latin 'Manichaei', being the genit. sing. of Manichaeus, either means 'of Mani' or 'of a Manichaean'. Without any doubt it here means 'of Mani' (who's name, as a rule-cf. Augustinus, haer. 46, 1-, was rendered into Latin as 'Manichaeus'). See below, n. 62, on my opinion that Coyle unnecessarily casts doubts on the meaning of 'Manichaei' in conf. $\mathrm{V}, 7,12.13$.

39) Namely in the dicta of the (unspecified) philosophers, of which Augustine in a previous paragraph has remarked that he had read (legeram) them and had retained their messages (mandata) in his memory and, moreover, that he had compared some of their teachings with the lengthy fables of the Manichaeans. See conf. V, 3, 3 (CCL 27, 58): 'Et quoniam multa philosophorum legeram memoriaeque mandata retinebam, ex eis quaedam comparabam illis manichaeorum longis fabulis'.

40) I.e., scientific knowledge, philosophical system.

41) All of the best and well-known ancient mss. read 'quae', not 'qui'. The common English translation 'who wrote / has written...' is not supported by any of these ancient mss. of the Latin text. According to M. Skutella (S. Avreli Avgvstini Confessionvm libri tredecim [Lipsiae MCMXXXIV]. Editionem correctiorem cvravervnt H. Jvergens et W. Schavb, Stvtgardiae et Lipsiae 1996, 80), it is only the editions of J. Amerbach (Basiliae 1489) and A.C. Vega (Escurial 1930) that read 'qui' and 'qui et' resp. Cf. the edition of M. Skutella reprinted in Bibliothèque Augustinienne 13, Paris 1962, 472. According to J.-P. Migne (MPL 32, Parisiis 1845, 708), the editions of H. Sommalius (Coloniae Agrip[p]inae 1629), D. Dubois (Parisiis 1687), J. Martin (Parisiis 1741) and L.St. Rondet (Parisiis 1776) read 'qui' as well. However, it is only in regard to Martin and Rondet that Migne (MPL 32, 661-662) makes mention of a personal consultation of mss. (some of which, so one may infer, might have read 'qui'). To the supporters of 'qui' I may add Erasmus (Omnium Operum D. Avrelii Avgvstini Hipponensis Episcopi, Tomus Primus, Basiliae 1529 = Basiliae 1543, 99), but it is a commonly known fact that in the case of Erasmus' edition of Augustine the phrase on the 
and foolishly. I did not discover any rationale (ratio) either of the solstices and the equinoxes, or the eclipses of the luminaries, or anything of the kind I had learned in the books (libri) of secular wisdom. Yet I was ordered to believe therein, ${ }^{42}$ but it $^{43}$ was not in agreement with those rationales (rationes) acknowledged by calculation which I also had observed with my own eyes. It ${ }^{44}$ was very different. ${ }^{45}$

A first key word in this passage is the noun dictum. For the young Augustine there were, on the one hand, the dicta of the philosophers and, on the other, the dicta of Mani. In regard to the philosopher's statements, he has expressly said that he has read them in their books. ${ }^{46}$ It is difficult to understand why Augustine, who in the same vein speaks about the dicta of Mani and, moreover, explicitly says that Mani has written on these subjects before again recalling his reading of 'the books of secular wisdom', in the case of the doctrines of Mani would have restrained himself to oral information. Already a close reading of only this paragraph, so I would say, unequivocally points into another direction. In full accordance with his previous and independent investigation of other books (after his curriculum study of 'the textbooks on eloquence' and Cicero's Hortensius ${ }^{47}$ he independently studied 'the holy scriptures', ${ }^{48}$ 'the books of the

title page 'ad fidem vetvstatorvm exemplarivm, post omnivm in hunc usque diem editiones denuo summa vigilantia repurgatorum à mendis in numeris' should be taken 'cum grano salis'. Curiously the famed French edition of P. de Labriolle, Saint Augustin, Confessions. Livres I-VIII, Tome I, Paris 1925, 96) reads 'quae', but translates: '... déclarations de Manichée, qui a écrit...', like E. Tréhorel and G. Bouissou translate in BA 13, 473.

42) That is: 'in those sayings of Mani'.

43) Or: 'he', namely Mani in his dicta.

44) Or: 'he', i.e., his account.

45) Conf. V, 3, 6 (CCL 27, 59-60): 'Multa tamen ab eis ex ipsa creatura uera dicta retinebam, et occurrebat mihi ratio per numeros et ordinem temporum et uisibiles attestationes siderum et conferebam cum dictis Manichaei, quae de his rebus multa scripsit copiosissime delirans, et non mihi occurrebat ratio nec solistitiorum et aequinoctiorum nec defectuum luminarium nec quidquid tale in libris saecularis sapientiae didiceram. Ibi autem credere iubebar, et ad illas rationes numeris et oculis meis exploratas non occurrebat et longe diuersum erat'.

46) See conf. V, 3, 3 in n. 39. Cf., moreover, conf. V, 3, 4 (CCL 27, 58): 'et scripserunt (sc. philosophi) regulas indagatas, et leguntur hodie'.

47) Conf. III, 4, 7 (CCL 27, 29-30): 'discebam libros eloquentiae... et usitato iam discendi ordine perueneram in librum cuiusdam Ciceronis ... liber ille... uocatur Hortensius'.

48) Conf. III, 5, 9 (CCL 27, 30-31): 'Itaque institui animum intendere in scripturas sanctas et uidere, quales essent'. 
horoscope-casters' ${ }^{49}$ Aristotle's Categories, ${ }^{50}$ 'all the books that I could get of the so-called liberal arts', ${ }^{51}$ and, as he later on relates, he had done 'much reading in the philosophers' ${ }^{\prime 52}$ ), he also, and by himself, studied the Manichaean writings.

All of this seems to be implied not only by the passage just quoted, and by the cumulative evidence from the previous text and the texts discussed further on in this article, but may also be inferred from the fact that nowhere in Manichaean literature it is stated that the right to study Mani's and other Manichaean writings is restricted to the Elect alone. Augustine's status as a Hearer is particularly associated with his having a concubine and, for instance, the secular career he pursued. As such a Hearer, he attends Manichaean worship (oratio) where Mani's writings (among which in any case Mani's Epistula Fundamenti) are being read as holy Scripture. ${ }^{53}$ This is comparable with the Catholic Christian reading of holy Scripture during Church service. Such a reading by no means excludes any personal study of the Scriptures by the individual believer.

Other pertinent passages are found in Confessiones V, 7, 12-13. Here Augustine relates his initial estrangement from the Manichaeans after he had met Bishop Faustus. At the end of the year 382, or at the beginning of 383, Bishop Faustus had finally arrived at Carthage and shortly afterwards a private meeting took place between Augustine, accompanied by his close friends, ${ }^{54}$ and the much applauded Manichaean bishop. From a scientific and doctrinal point of view, the meeting turned out to be a disappointment and the young Augustine's doubts increased. It should be noted, however, that Augustine-eager to know a number of peculiarities of Mani's doctrine and, moreover, unsatisfied by what he heard in the general

49) Conf. IV, 3, 5 (CCL 27, 42): 'ubi cognouit ex conloquio meo libris genethliacorum esse me deditum.... See also the particular context in which stress is laid on (independent) study.

50) Conf. IV, 16, 28 (CCL 27, 54): 'cum in manus meas uenissent Aristotelica quaedam, quas appellant decem categorias... legi eas solus et intellexi'.

51) Conf. IV, 16, 30 (CCL 27, 55): 'omnes libros artium, quas liberales uocant, tunc nequissimus malarum cupiditatum seruus per me ipsum legi et intellexi, quoscumque legere potui'.

52) Conf. V, 3,3 (CCL 27, 58): 'quoniam multa philosophorum legeram'.

53) C. ep. Man. 5 (CSEL 25, 197): ‘... illum ... librum, quem Fundamenti epistulam dicitis, ubi totum paene, quod creditis, continetur. ipsa enim nobis illo tempore miseris quando lecta est, inluminati dicebamur a uobis'.

54) Conf. V, 6, 11 (CCL 27, 62): 'cum familiaribus meis'. 
meeting(s) of the Bishop with his hearers ${ }^{55}$ - came to this private interview exceedingly well prepared. In the paragraphs following conf. V, 3, 6, Augustine has already related that Mani wrote on astronomical matters ${ }^{56}$ (though, according to the bishop writing his Confessiones, such things are not essential to learning pietas $^{57}$ and, moreover, has said explicitly that he tried to ascertain 'whether Mani's uerba offered a possible explanation consistent with the changes of longer and shorter days and nights, and of day and night itself, with the eclipses of the greater lights (i.e. the sun and moon), and whatever else of the kind I had read about in other books ${ }^{58}$ Here he says that 'their (sc. the Manichaeans') books are full of immensely lenghty fables about the heaven and stars and sun and moon'. ${ }^{59}$ Immediately after this statement Augustine formulates the serious doubts that assailed him in those days: 'I had ceased to think Faustus able to subtly explain what I ardently desired: whether, after comparing the mathematical calculations I had read elsewhere, the explanations contained in the books of Mani were

55) Conf. V, 6, 11 (CCL 27, 62): 'in coetu audientium'. Augustine seems to avoid here the Manichaean technical term 'auditores'. One may suppose that both the Carthaginian Elect (they, in particular, seem to have been unable to answer Augustine's questions) and the Hearers proper did attend Faustus' discourses. Not only the word 'multi', but also 'coetus' seems to indicate that the Manichaean community at Carthage was of a considerable size. This must also have been the case with e.g. the community in Rome, for which see e.g. conf. V, 10, 18-19 (CCL 27, 67-68), where it runs in 19 that 'plures enim eos [sc. Manichaeos] Roma occultat' (praesens!; though the rather famous but, in actual fact, not so reliable Sessorianus ms. reads 'occultabat', a reading which is followed by Skutella and by his successors Jürgens and Schaub, S. Avreli Avgvstini Confessiones [n. 41], 80, and which also turns up in S. Avreli Avgustini Confessionvm libri tredecim ex recognitione P. Knöll, Lipisiae 1926, 88, in the edition of De Labriolle (n. 41), I, 108, and in The Confessions of Augustine. Edited by John Gibb \& William Montgomery, Cambridge 1927, 128). However, the majority of the mss., like e.g. the editions of Erasmus (n. 41, 104), Migne (n. 41, 715), J.J. O’Donnell (Augustine, Confessions, I, Introduction and Text, Oxford 1992, 54) and even BA 13, 498 (which officially 'reproduit l'édition critique de M. Skutella', $B A 13,6$ ) read 'occultat'.

56) This included what we presently term 'astrology'. It might be recalled that, in Antiquity, there was no real distinction between 'astronomy' and 'astrology'.

57) Conf. V, 5, 8 (CCL 27, 60): 'sine quorum peritia pietas disci poterat'.

58) Conf, V, 5, 9 (CCL 27, 61): 'Sed tamen nondum liquido compereram, utrum etiam secundum eius uerba uicissitudines longiorum et breuiorum dierum atque noctium et ipsius noctis et diei et deliquia luminum et si quid eius modi in aliis libris legeram, posset exponi'. Already the phrase 'in aliis libris' appears to be, by inference, a clear indication of Augustine's reading of Mani's books!

59) Conf. V, 7, 12 (CCL 27, 63): 'Libri quippe eorum pleni sunt longissimis fabulis de caelo et sideribus et sole et luna'. 
preferable, or at any rate equally sound'. ${ }^{60}$ Significantly, the story of his meeting with Faustus is also concluded with the unequivocal remark: 'In consequence the enthusiasm (studium) I had for the writings of Mani was broken down'. ${ }^{61}$

On the basis of these testimonies it should be clear that Augustine, already during his Manichaean years, not only had access to the writings of $M a n i,{ }^{62}$ i.e. to the Manichaeans' canonical books, but also eagerly studied them. I do not see any reason to deny this evidence or to detract in some way from a plain fact. One may add that such a personal and close reading of writings is characteristic of the subsequent phases of Augustine's spiritual journey as well: just like the young rhetor did before he met Faustus, ${ }^{63}$ so in his later years too he will actively study all writings that cross his path. The writings expressing 'Academic' ideas probably belong in this category; ${ }^{64}$ an active reading certainly applies to the books of the Neoplatonists, ${ }^{65}$ to

60) Conf. V, 7, 12 (CCL 27, 63): 'quae mihi eum [sc. Faustum], quod utique cupiebam, conlatis numerorum rationibus, quas alibi ego legeram, utrum potius ita essent, ut Manichaei libris continebatur, an certe uel par etiam inde ratio redderetur, subtiliter explicare posse iam non arbitrabar'.

61) Conf. V, 7, 13 (CCL 27, 63): 'Refracto itaque studio, quod intenderam in Manichaei litteras'. Note that, of course, 'studium' may also be translated as 'study'. It is highly significant that Faustus does refer to both Mani and Adimantus as those persons whose writings should be studied. See below, n. 96. See also n. 83 on the varied meaning of 'litterae'.

62) There is no reason to suppose with Coyle ('Augustine's Manichaean Legacy', 13, in reference to conf. V, 7, 12. 13; cf. 'What Did Augustine Know', 48) that 'Manichaei' would refer here to works 'from other close followers, or simply writings in use among them'. In this case Augustine would have written 'Manichaeorum' (cf. e.g. conf. V, 3, 3 in n. 39), not 'Manichaei'.

63) Cf. the references given in nn. 58 and 60-61. See, moreover, for Augustine's habit of independent study p. 453-454 and nn. 47-52.

64) Augustine seems to have made his first and main acquaintances with the ideas of the so-called New Academy via Cicero. See e.g. Alfaric, Évolution, I (n. 6), 264-269.273; M. Baltes, 'Academia', $A L 1$ (1986 sqq.) 43; B.R. Voss, 'Academicis (De -)', ibidem, 47. It is plausible to posit an advanced study of Cicero's writings (and thus, by implication, of 'Academic' ideas) in those years. Cf., for instance, H. Hagendahl, Augustine and the Latin Classics, Göteborg 1967, 479-588, in particular 498-499: 'In Rome and Milan he went through a period of scepticism during which the Academics seemed to him to be the wisest of all philosophers because they denied the possibility of perceiving the truth. It was, no doubt, through Cicero that he became familiar with their opinions'.

65) Conf. VII, 9, 13 (CCL 27, 101): '... procurasti mihi per quendam hominem immanissimo typho turgidum quosdam Platonicorum libros ex graeca lingua in latinam uersos, et ibi legi...'; VII, 20, 26 (CCL 27, 109): 'Sed tunc lectis Platonicorum illis libris...'. 
the biblical books in general, ${ }^{66}$ and to Isaias, ${ }^{67}$ the Psalms ${ }^{68}$ and St Paul ${ }^{69}$ in particular. Once in Milan, in the course of his thirtieth year and still involved in the quest of real wisdom, Augustine is so busy with his secular career, that-like some sort of 'helluo librorum'-he characteristically bemoans his situation with the words: 'There is no time for reading!'70

\section{Other Evidence}

On the issue of Augustine's acquisition of knowledge of Manichaeism two important points remain to be dealt with. First there is the question: If not as a young Manichaean, that is during his many years as a Hearer, in which way and at what particular time would Augustine have acquired his strikingly thorough knowledge of Manichaeism? Closely connected (and partly intertwined) with this matter is the second main question: Is thereapart from Augustine's case-other evidence that 'ordinary' Hearers had access to Manichaean writings and even to the (canonical) writings of Mani himself?

Evidence that may provide an answer to the first question is amply supplied by Augustine himself. Already in one of the early writings after his conversion to Catholicism, i.e. in the twofold work De moribus of about 388-389, he dares to remark: 'This is not what we find in the books of Mani: there it is constantly implied and constantly asserted that God guarded

66) E.g. conf. VII, 21, 27 (CCL 27, 110): 'Itaque auidissime arripui uenerabilem stilum spiritus tui'.

67) Conf. IX, 5, 13 (CCL 27, 140): 'At ille [sc. Ambrosius] iussit Esaiam prophetam.... Verum tamen ego primam huius lectionem non intellegens...'.

68) Conf. IX, 4, 8 (CCL 27, 136): 'Quas tibi, deus meus, voces dedi, cum legerem psalmos David'.

69) Conf. VII, 21, 27 (CCL 27, 110): 'Itaque auidissime arripui uenerabilem stilum spiritus tui et prae ceteris apostolum Paulum'. Cf. e.g. VIII, 12, 29.

70) Conf. VI, 11, 18 (CCL 27, 86): '... non uacat legere'. The sequel is not less characteristic: 'Vbi ipsos codices quaerimus? Vnde aut quando comparamus? A quibus sumimus?'.-It may be noted in passing that Augustine, when telling the story of his life in the conf., always speaks of his reading of codices. In regard to Ambrose, however, like in the case of Faustus, he speaks of their reading of uolumina, i.e. scrolls (conf. V, 6, 11: '... si qua uolumina latine atque composite conscripta erant'; VI, 3, 3: '... minus quam uellet uoluminum euolueret'). Maybe this is a characteristic of the younger person availing himself of the then (in actual fact: once again) 'hottest' means of collecting data which, moreover, seem to have been most swift and saving? 
against an invasion of His enemies' ${ }^{71}$ One may ask: Since when does Augustine know this; and on the basis of which data can he state this so categorically? In the two treatises De moribus, there is no shred of evidence indicating that for the purpose of writing this severe and expert critique the author first sat down to study Manichaean texts. However, in this work Augustine's acquaintance with both the Manichaean mores and their doctrines is astonishingly intimate. ${ }^{72}$

When, in De moribus, Augustine occasionally remarks that the Manichaeans say something, this should not lead us astray into claiming that all this information is based on oral sources. ${ }^{73}$ In actual fact verbs like dicere and perhibere, ${ }^{74}$ or a common expression like inquiunt ${ }^{75}$ usually indicate nothing other than: such is Manichaean doctrine and habit. If phrases like 'they say' or 'they bring forward' on the one hand and 'let us hear' or (sometimes even) 'I heard' are taken as an unequivocal indication of Augustine's Hearer status, and hence, by inference, of his data being limited to information acquired only orally, why does he so boldly declare: 'Non hoc sonant libri Manichaei'?76 And why, in the case of the Catholic holy Scriptures and the writings of certain 'learned men' (all of which he certainly read and even studied intensively!), does he also repeatedly remark that 'they say' or that 'they are (or: should be) heard'? ${ }^{77}$ As it is the case in an early work like the Acta contra Fortunatum Manichaeum, so expressions

\footnotetext{
71) Mor. II, 12, 25 (CSEL 90, 110): 'Non hoc sonant libri Manichaei; cauisse Deum ne inuaderetur ab hostibus, saepissime ibi significatur, saepissime dicitur'.

72) See e.g. what he tells about the 'congruity' (congruentia) in the kingdom of darkness according to 'your author' (auctor uester: mor. II, 9, 17; CSEL 90, 102), about the Manichaeans' three seals (tria signacula: mor. II, 10, 19 sqq.; CSEL 90, 104 sqq.) and many other Manichaean mores, and e.g. the just (n. 71) quoted remark: 'Non hoc sonant libri Manichaei'. Cf. e.g. Augustine's reference to 'the words of your founder' (auctorem ipsum uestrum: mor. II, 17, 55; CSEL 90, 138).

73) Thus the suggestion made by Coyle, 'Wat did Augustine know' (n. 19), 47 and n. 20.

74) E.g. mor. II, 9, 14 (CSEL 90, 100); mor. I, 10, 16 (CSEL 90, 19).

75) E.g. mor. II, 16, 38 (CSEL 90, 123).

76) The use of the verb sonare does not imply that Augustine made his acquaintance with these works because they were read aloud to him. One may bear in mind that reading aloud whilst studying a text was usual in antiquity.

77) Of the numerous expressions in mor., reference may be made to only a few. See e.g. mor. I, 7, 12: 'sed potius audiamus oracula nostrasque ratiunculas diuinis submittamus affatibus'; I, 17, 32: 'Audite itaque aliquando et aduertite quaeso sine pertinacia quid per prophetam dicatur'; I, 18, 34: 'audite doctos Ecclesiae catholicae uiros'.
} 
such as 'dicitis' and 'fatemini'-like 'audiui' or 'audiamus' in the passages quoted from De moribus - may very well refer to written sources. ${ }^{78}$

Apart from the main evidence adduced from the Confessiones, we may add here some other testimonies. They are a further indication that the young Augustine, i.e. Augustine the Manichaean from 373 to about 383, in addition to the oral information provided to him as an 'ordinary' Hearer, must have had a special knowledge of the tenets and texts of the Manichaeans acquired through a careful and even comprehensive study of their writings.

It is largely correct when Coyle points to the fact that Augustine in later phases of his life acquired Adimantus' Disputationes, Faustus' Capitula, the Letter of Secundinus, and the Letter to Menoch. But it is largely incorrect to state that 'over the course of his entire literary career he only quotes from the Manichaean literary corpus infrequently, in each instance from writings recently acquired'.$^{79}$ In order to substantiate this judgement, Coyle refers to Mani's Treasure of Life, the Letter of the Foundation, the Letter to Menoch, and finally to the writings of Faustus and Secundinus. ${ }^{80}$ But, at least as far as Mani's Epistula Fundamenti and his Thesaurus is concerned, this claim does not apply. On the contrary, already in the dispute with the Manichaean presbyter Fortunatus during two days in August 392 Augustine testifies to a thorough knowledge of (at least) Mani's Epistula Fundamenti and Thesaurus. ${ }^{81}$

This precise knowledge we find confirmed in, exempli gratia, Augustine's Contra Epistulam Manichaei quam uocant Fundamenti (about 396) and in Contra Felicem (404). In the case of Contra Epistulam Manichaei it is evident that Augustine had an (annotated) copy of Mani's Letter at his disposal..$^{82}$ But nowhere is it said that he had acquired this Letter recently, nor does he anywhere give the impression that its contents are new to him.

78) J. van Oort, 'Heeding and Hiding their particular Knowledge? An Analysis of Augustine's Dispute with Fortunatus', in: T. Fuhrer (Hrsg.), Die christlich-philosophischen Diskurse der Spätantike, Stuttgart 2008, 113-121.

79) Coyle, 'What Did Augustine Know', 50; idem, 'Augustine's Manichaean Legacy', 14.

80) Coyle, 'What Did Augustine Know', 50 n. 36; idem, 'Augustine's Manichaean Legacy', 14 n. 14. Cf. Coyle's Augustine's "De moribus ecclesiae catholicae" (n. 16), 23.

81) Cf. Van Oort, 'Heeding and Hiding their particular Knowledge', 120-121.

82) Retr. II, 2, 1 (CCL 57, 91): 'Liber contra epistulam Manichaei quam uocant fundamenti principia eius sola redarguit; sed in ceteris illius partibus adnotationes ubi uidebatur adfixae sunt, quibus tota subuertitur et quibus commonerer, si quando contra totam scribere vacuisset'. 
Rather, the evidence points in another direction: Augustine criticizes a text the subject matter of which he is thoroughly familiar with. Moreover, it should be noted that already here he ventures to speak about the precise contents of other 'works' or 'letters of Mani' ${ }^{83}$

The very same impression is obtained from the dispute with Felix. In this instance the (confiscated) works of Mani are tabled, the 'quinque auctores' to which, in any case, the Epistula Fundamenti and the Thesaurus turn out to belong. ${ }^{84}$ Admittedly, this dispute takes place in 404 and one might suppose that in the meantime Augustine has made considerable progress in studying Mani's writings. But where is the evidence for such a detailed study after his Manichaean period has elapsed? What strikes the unprejudiced reader of Contra Felicem, rather, is the important detail that, suddenly in the course of the dispute, Augustine expertly quotes Mani's Thesaurus in order to prove that Mani has a doctrine of free will. ${ }^{85}$

There are, moreover, also other occasions where Augustine surprisingly displays an intimate knowledge of Manichaeism and, not least, of Mani's own writings. Thus he suddenly remarks in Contra Faustum (c. 400): 'All of Mani's letters begin in this fashion: "Mani, apostle of Jesus Christus"'. ${ }^{86}$ Or, once again surprisingly and highly expertly: 'Do you recall your Song of the Lovers in which you describe the supreme reigning monarch, forever sceptre-bearing, crowned with flowers and of fiery countenance? ${ }^{87}$ After this evocative question, Augustine, as a real specialist, displays his intimate knowledge of Manichaean 'theology' by describing both the supreme God

83) C. ep. Man. 25, 28 (CSEL 25, 224): ‘... delere profecto Manichaei litteras non potestis: non dico alias, quibus expressius ista descripsit'. It is significant of his own singular position, that Augustine, while addressing the Manichaeans directly, adds that, because the Manichaean litterae are in the hands of only a few (and he himself expresses his belonging to those few!), their contents will cause less difficulty to (the majority of) them.- The passage is somewhat unclear because of Augustine's polysemic use of the term litterae as 'letters' (of the alphabet), 'letters' (epistles) and 'written documents'. But anyway, he himself indicates his particular knowledge, either of Mani's Letters other than the Epistula Fundamenti, or of Mani's other writings.

84) C. Fel. I, 14 (CSEL 25, 817).

85) C. Fel. II, 5 (CSEL 25, 832-833).

86) C. Faust. XIII, 4 (CSEL 25, 381): 'omnes tamen eius epistulae ita exordiuntur: Manichaeus apostolus Iesu Christi'.

87) C. Faust. XV, 5 (CSEL 25, 425): 'annon recordaris amatorium canticum tuum, ubi describis maximum regnantem regem, sceptrigerum perennem, floreis coronis cinctum et facie rutilantem?'. 
and his kingdom of worshipping deities. ${ }^{88}$ Even near the end of his life, we suddenly witness such an unexpected proof of his expertise: on the basis of his intimate knowledge of Mani's writings, Augustine doubts the genuineness of Mani's so-called Letter to Menoch. ${ }^{89}$

In actual fact, I consider all this 'other evidence' ${ }^{\prime 0}$ as nothing more than some additional proof to the already clear testimony in Augustine's narration of his early life story. From the Confessiones it is clear that, during his years as a Manichaean Hearer, Augustine read and actively studied Manichaean writings and, evidently, also works of Mani himself. To those who still suppose that Augustine only after his Manichaean years became acquainted with Manichaean writings, this supplementary 'other evidence' may add little or nothing. In that case, however, the burden of proof lies with those who argue this point to demonstrate when exactly Augustine entered his studium of the Manichaean writings and, closely connected with this issue, at which moment these writings became accessible to him.

As far as I can see, such a substantiation will be conclusive only with regard to Faustus' Capitula and to Secundinus' Epistula. ${ }^{91}$ For, even in the case of Adimantus' Disputationes one may doubt whether these were so novel to Augustine as may be supposed from the information that, at a

88) C. Faust. XV, 5-6 (CSEL 25, 425-428).

89) C. Iul. imp. III, 172 (CSEL 85, 1, 473): ' Si dicam tibi istam Manichaei epistulam me omnino nescire' etc.

90) It may be supplemented by several other texts; see e.g. for Augustine's testimonies to his profound knowledge of the Manichaean myth and a number of other Manichaean doctrines in ciu. my 'Manichaeism in Augustine's De ciuitate Dei', in: E. Cavalcanti (ed.), Il 'De ciuitate Dei': L'opera, le interpretazioni, l'influsso, Roma-Freiburg-Wien 1996, 193-214.

91) C. Faust. I, 1 (CSEL 25, 251): 'hic [sc. Faustus] quoddam uolumen edidit aduersus rectam christianam fidem et catholicam ueritatem. quod cum uenisset in manus nostras lectumque esset a fratribus, desiderauerunt et iure caritatis, per quam eis seruimus, flagitauerunt, ut ei responderemus'. With F. Decret ('Faustum Manicheum (Contra -)', $A L 2,1245)$ one may argue that, because in his references to Faustus in conf. Augustine does not mention the Capitula, he may have become acquainted with Faustus' work somewhere after 400 and, because of a notice in one of his letters to Jerome (ep. 82, 17), that he composed his $c$. Faust. sometime between 400-404. As regards Secundinus' Letter, see my preliminary remarks in 'Secundini Manichaei Epistula: Roman Manichaean 'Biblical' Argument in the Age of Augustine', in: J. van Oort a.o. (eds.), Augustine and Manichaeism in the Latin West (n. 19), 161-173 (163 and nn. 5-7 for references to its likely date of composition and of Augustine's answer). 
certain point at the beginning of his ecclesiastical office, 'some disputations of Adimantus fell into my hands'. ${ }^{92}$ In his first endeavour to give an explanation of the Creation story in Genesis, i.e. in his De Genesi aduersus Manichaeos which is usually dated to the years 388-389/390, Augustine clearly indicates that he was well acquainted with, in any case, part of these Disputationes. ${ }^{93}$ This, then, was at a moment long before he finally edited his Contra Adimantum, namely sometime between the end of 393 and the summer of 394. ${ }^{94}$ It may even be supposed that, apart from De Genesi aduersus Manichaeos, already Augustine's account of his first meeting with the Manichaeans reveals important reminiscences of the young Augustine becoming familiar with the contents of Adimantus' Disputationes. ${ }^{95}$ In this context, moreover, it is important to draw attention to Faustus' remark that, apart from Mani's writings, it is Adimantus who should be studied. ${ }^{96}$ It is not only quite possible but even quite likely that Augustine's typical activities as a Manichaean, namely ardently proselytizing amongst and vehementely disputing with Catholic Christians, ${ }^{97}$ may have made him acquainted with its contents at an early stage of his Manichaean career. Of

92) Retr. I, 22, 1 (CCL 57, 63): 'Eodem tempore uenerunt in manus meas quaedam disputationes Adimanti.... From the context it may be inferred that the expression 'eodem tempore' in any case refers to a date after Augustine's being ordained a priest (i.e. after the spring of 391) and before his becoming a bishop (most probably in 395).

93) Cf. Gn. adu. Man. I, 22, 33 (CSEL 91, 101) with Adimantus' argument according to $c$. Adim. 2 (CSEL 25, 116-117). I owe this reference as well as much of the following to J.A. van den Berg's nearly finished Nijmegen dissertation on Adimantus and his Disputationes.

94) Cf. e.g. F. Decret, 'Adimantum Manichei discipulum (Contra -)', $A L$ 1, 91.

95) The account of conf. III, 7, 12-13 ff. clearly indicates striking parallels between many of Adimantus' Disputationes. I already referred to a number of these parallels in my Jerusalem and Babylon (n. 14), 37-39.

96) C. Faust. I, 2 (CSEL 25, 251-252): 'Satis superque in lucem iam traductis erroribus ac Iudaicae superstitionis simul et semichristianorum abunde detecta fallacia a doctissimo scilicet et solo nobis post beatum patrem nostrum Manichaeum studendo Adimanto non $\mathrm{ab}$ re uisum est, fratres carissimi, haec quoque breuia uobis et concinna responsa propter callidas et astutas conferentium nobiscum propositiones scribere, quo cum idem uos ex more parentis sui serpentis captiosis circumuenire questiunculis uoluerint, et ipsi ad respondendum uigilanter eis sitis instructi'.

97) See already a text like conf. IV, 1, 1 (above, n. 26: 'seducebamus'). Cf. e.g. agon. 4, util. cred. 2 and, not least, duab. an. 11 (CSEL 25, 65-66): '... alterum, quod quaedam noxia uictoria pene mihi semper in disputationibus proueniebat disserenti cum christianis inperitis, sed tamen fidem suam certatim, ut quisque posset, defendere molientibus christianis. quo successu creberrimo gliscebat adulescentis animositas...'. 
course it should be kept in mind that Augustine was an acute debater, ${ }^{98}$ well trained in all of the rhetorical skills, an ability he also used in his struggle with the Manichaeans after his return to the Catholic Church. ${ }^{99}$ But apart from this 'talent', so he himself explicitly says, he attributed his Manichaean debating success 'to other readings' ${ }^{100}$ What else could be meant here than Manichaean writings? It is these Manichaean writings, and not least the writings of Mani himself, which powerfully and intimately shaped Augustine's thought to the extent that, sometime in the early years of his ecclesiastical office, he could arrange some five of his writings against the Manichaeans in a sort of anti-Manichaean Pentateuch directly counteracting the five canonical books of Mani. ${ }^{101}$

Was it, then, possible for any 'ordinary' Hearer to acquire such an intimate knowledge? Apart from the passages from the Confessiones already referred to (amongst which the information about the unknown African bishop seems to be particularly telling), ${ }^{102}$ one may refer to a Hearer like a

98) Cf. e.g. T. Fuhrer, 'Disputatio', $A L$ 2, 504-508 and H. Ruef, 'Dialectica, dialecticus', $A L$ 2, 407-413.

99) As it is attested by, e.g., c. Fort. and c. Fel.

100) Duab. an. 11 (CSEL 25, 66): 'quod altercandi genus quia post eorum [sc. Manichaeorum] auditionem adgressus eram, quicquid in eo uel qualicumque ingenio uel aliis lectionibus poteram, solis illis libentissime tribuam.'

101) See among the collection of letters of Augustine ep. 24, 2 (Paulinus of Nola and his wife Therasia to Augustine's friend Alypius who had provided them with five books by Augustine directed against the Manichaeans): 'Accepimus enim insigne praecipuum dilectionis et sollicitudinis tuae opus sancti et perfecti domino Christo uiri, fratris nostri Augustini, libris quinque confectum...' and ep. 25,2 (Paulinus and Therasia to Augustine): 'Ideoque cum hoc Pentateucho tuo contra Manichaeos me satis armaueris...'. Both letters were, according to A. Goldbacher in his edition (CSEL 58, 12), and also according to J. Divjak in AL2, 938 and 1027-1028, written in 394.-It is interesting to speculate about the contents of both the Manichaean and the Augustinian 'Pentateuch'. Without going into all the particular aspects of the question, one may say that Mani's main canonical writings will have comprised his Gospel, Thesaurus, Pragmateia, Book of Mysteries, and Book of the Giants. It seems likely that, in the Latin West and in any case in Africa, the place of his Gospel was (partly?) substituted by his Fundamental Letter; cf. e.g. $c$. Fel. I, 14 (from which passage we also may deduce that all of the five canonical writings of Mani referred to had been translated into Latin). As regards Augustine's anti-Manichaean Pentateuch, it might well have consisted of lib. arb. (cf. c. Sec. 11 [CSEL 25, 923]: ' . . lege tres libros nostros, qui inscribuntur "de libero arbitrio", quos in Campania Nolae poteris inuenire apud Paulinum nobilem dei famulum'), util. cred., Gn. adu. Man., mor., and duab. an.

102) Admittedly, it is not explicitly stated that he was a Hearer, but what else could such a paruulus have been? Moreover, there is no attestation from elsewhere that a former Manichaean Elect later on became a Catholic bishop. 
certain Constantius who in Rome tried to gather together the wandering Elect in his house in order to live 'according to the rule of life in the Letter of Mani'. ${ }^{103}$ In some way or another, this Hearer seems to have had access to (some part of) Mani's literary legacy. Besides, all we know of another Hearer in the capital, the previously discussed Secundinus, comes from his Letter to Augustine: apart from a remarkable knowledge of the Bible (including the writings of the 'Jewish tribes with their barbaric customs'), even in this relatively small piece of writing Secundinus clearly seems to display an acquaintance with the writings of Mani. ${ }^{104}$ Perhaps one may also add to this class of Hearers the unnamed one who was Augustine's host in Rome. Augustine, by then coming under the influence of Academic scepticism, remarks that he did not neglect 'to tell my host frankly to restrain that assurance which I observed him to have in those fabulous matters of which the books of Mani are full'. ${ }^{105}$ Though it is not explicitly said that this Hearer himself read Mani's books, it is at least suggested from the wider context and, moreover, the impression is created that the (by then increasingly sceptical) Hearer Augustine discussed some aspects of the contents of Mani's books with him.

\section{Conclusion}

At the end of our rather long journey, we may bring to mind some of the main perspectives that turned up.

When considered in combination, all evidence appears to point into one direction: it was already the young Augustine who acquired a thorough knowledge of Manichaeism. Moreover, it is very likely that he himself, being at the same time an ardent adherent of the Manichaeans and their fervent propagandist, obtained this thorough knowledge by studying

103) Mor. II, 20, 74 (CSEL 90, 155): 'Proposita est uiuendi regula de Manichaei epistola'. With reference to $c$. Faust. V, 5 (CSEL 25, 277: '... ille Constantius... qui multos uestrum Romae in domum suam congregauerat propter inplenda praecepta Manichaei...'), it is generally assumed that the person who in mor. II is the anonymous founder of some sort of Manichaean convent or monastery in Rome was the Hearer Constantius.

104) Cf. my 'Secundini Manichaei Epistula' (n. 91), 163-164.

105) Conf. V, 10, 19 (CCL 27, 19): 'Nec dissimulaui eundem hospitem meum reprimere a nimia fiducia, quam sensi eum habere de rebus fabulosis, quibus manichaei (lege: Manichaei!) libri pleni sunt'. 
Mani's writings independently. To all this Augustine's Confessiones in particular bear witness. Furthermore, it is from Augustine's account in this work that we may get a unique glimpse of the use of pictorial books in the Manichaeans' missionary activity in Roman Africa. In all likelihood Augustine's Confessiones testify to the existence in the Latin West of the so-called Image, the painted picture book illustrating Mani's doctrine.

In several instances Augustine indicates that he gained his knowledge by reading Mani's writings while he was still an 'ordinary' Hearer. The fact that, in this respect, he was no exception, is evidenced by comparison with other Hearers spoken of in his œuvre like Constantius and Secundinus. It is with reference to this Hearer status that, finally, we may adduce some newly discovered evidence.

Since the early nineties of the previous century, new discoveries of Manichaean documents have been made in the Egyptian Dachleh Oasis at the site of ancient Kellis. It is here that a number of manuscripts have been unearthed which strongly indicate that Manichaean Hearers as well as Elect were involved in the copying of texts. The (young) Hearers' involvement may be inferred from the wide range of psalms often written in unpracticed handwritings, ${ }^{106}$ but in particular from one of the personal letters sent by a certain 'father' Makarios to his 'son' Matheos. This Matheos, evidently a young Manichaean Hearer, is not only encouraged to copy Manichaean books (apparently including books of Mani himself), but also to study them. ${ }^{107}$

It is precisely when taking into account an early and thorough study of Mani's and other Manichaean writings, so it seems to me, that one may understand Augustine's astonishingly intimate knowledge of matters Manichaean. ${ }^{108}$ Only thus does it become comprehensible that, time and again

106) I. Gardner, A. Alcock and W.-P. Funk, Coptic Documentary Texts from Kellis, Volume 1, Oxford 1999, 77.

107) See P. Kell. Copt. 19 in Gardner et al., idem (n. 106), 156-165, in particular 160: 'Study [your] psalms, whether Greek or Coptic, <every> day (?) ... Do not abandon your vow. Here, the Judgment of Peter is with you. [Do the] Apostolos; or else master the Great Prayers and the Greek Psalms. Here too, the Sayings are with you: study them! Here are the Prostrations. Write a little from time to time, more and more. Write a daily example, for I need you to write some books here'. Cf. e.g. ibidem, 174.

108) Apart from the texts mentioned above, at this point I give only a brief overview of some indications which may be fruitfully studied in future: Augustine knows about the Manichaean doctrine of the wedge of darkness (uer. rel. 96); of God as the supreme (and immutable, incorruptible, impenetrable, inviolable) Good (mor. II, 3, 5); of the five dark provinces 
(though, as may be expected, in a public debate such as the one with Fortunatus no more than reluctantly), ${ }^{109}$ from his very first writings onwards Augustine can demonstrate such an expert knowledge of Manichaeism.

and five elements (mor. II, 9, 14); that once Darkness desired Light (mor. II, 9, 17); that the bipeds acceded to the persuasion of one of their kin and set out to wage war against God (mor. II, 9, 17); that God created the world out of the mixture of good and evil elements (mor. II, 9, 14-17; uer. rel. 9); that the sun must be adored (mor. II, 8, 13; Gn. adu. Man. II, 25, 38); of the Five Caves in the Land of Darkness (mor. II, 9, 14); of the animals born of the five dark elements in the Caves of the Kingdom of Darkness (mor. II, 9, 17); of the fall of the abortions (mor. II, 9, 14 and 17, 69); that plants suffer pain (mor. II, 17), etc. 109) In c. Fort., i.e. in the acts of a public disputatio at a time (392) when he is just a freshly consecrated Catholic presbyter, Augustine half-heartedly admits what he knows about Manichaean doctrine and practice; but he does: see e.g. the study on $c$. Fort. mentioned in n. 78 . 